\title{
The Phytochemistry and Biological Aspects of Caryocaraceae Family
}

ASCARI, J. ${ }^{* 1}$; TAKAHASHI, J.A.'; BOAVENTURA, M.A.D. ${ }^{1}$

${ }^{1}$ Departamento de Química, Instituto de Ciências Exatas, Universidade Federal de Minas Gerais, Av. Antônio Carlos, 6627, CEP 31270-970. Belo Horizonte, MG, Brazil. *jociascari@gmail.com

\begin{abstract}
RESUMO: Aspectos Fitoquímicos e Biológicos da família Caryocaraceae. A família Caryocaraceae é constituída por 25 espécies distribuídas em dois gêneros (Caryocar e Anthodiscus). Plantas desta família têm sido utilizadas em diversos estudos fitoquímicos para isolamento e caracterização de constituintes químicos. Alguns destes estudos avaliaram atividades biológicas in vitro e in vivo de extratos e substâncias puras isoladas a partir de plantas desta família. São descritas nove espécies dentro do gênero Anthodiscus e nenhum estudo fitoquímico relacionado a elas foi relatado. Por outro lado, o gênero Caryocar apresenta 16 espécies com diversos usos medicinais, tais como: para o tratamento de resfriados, bronquites, na prevenção de tumores, como reguladores do fluxo menstrual, em problemas oftalmológicos, e na cura de hematomas e contusões. Algumas espécies deste gênero foram submetidas a estudos fitoquímicos e apresentaram, em sua composição, as seguintes classes de metabólitos secundários: triterpenos, ácidos graxos, taninos, carotenoides, saponinas triterpênicas, cumarinas, glicosídeos fenólicos, entre outros. Os frutos de espécies Caryocar são muito nutritivos contendo em sua composição, fibras, proteínas, carboidratos e minerais. As sementes têm sido amplamente usadas como fonte de óleo com valor nutricional e cosmético. A avaliação biológica de algumas espécies foi realizada utilizando-se testes biológicos relevantes, entre eles: a atividade antioxidante, alelopática, antifúngica, contra Biomphalaria glabrata, e toxicidade sobre Artemia salina.
\end{abstract}

Palavras-chave: Caryocaraceae, Caryocar, Anthodiscus, constituintes fito-químicos, atividades biológicas, usos medicinais.

ABSTRACT: The Caryocaraceae family is constituted of 25 species distributed in two genera (Caryocar and Anthodiscus). Plants of this family have been used in several phytochemical studies for isolation and characterization of chemical compounds. Some of these studies evaluated in vitro and in vivo biological activities of extracts and pure substances isolated from plants of this family. Nine species of Anthodiscus genus have been described, while no phytochemical study related to them has been reported. On the other hand, Caryocar genus presents 16 species with several medicinal uses like for the treatment of colds and bronchitis, in the prevention of tumours, as a regulating agent of the menstrual flow, to treat ophthalmological problems and for the cure of hematomas and bruises. Some species of this genus were targeted by phytochemical studies and presented, in their composition, the following classes of secondary metabolites: triterpenes, fatty acids, tannins, carotenoids, triterpenic saponins, phenolic coumarins, phenolic glycosides, and others. The fruits of Caryocar species are very nutritive, containing in their composition fibers, proteins, carbohydrates and minerals. Seeds have been widely used as oil source with nutritional and cosmetic value. The biological evaluation of some species was carried out by using relevant biological assays such as: antioxidant, allelopathic and antifungal activities against Biomphalaria glabrata and toxicity on Artemia salina.

Key words: Caryocaraceae, Caryocar, Anthodiscus, phytochemical constituents, biological activities, medicinal uses.

\section{INTRODUCTION}

Caryocaraceae is a small botanic family, widely distributed in Central and South America, composed by 25 species, distributed in two genera,

Caryocar and Anthodiscus. Plants from Caryocar genus are very well studied especially because they are good sources of oils and wood, this latter

Recebido para publicação em 30/11/2011

Aceito para publicação em 28/11/2012

Rev. Bras. Pl. Med., Campinas, v.15, n.2, p.293-308, 2013. 
being of good quality due its hardness, resistance to humidity and to attacks by insects (Prance, 1990). Caryocar genus presents sixteen species some of which possess economical potential since their fruits are often used as a source of edible oil. Among Caryocar species, Caryocar brasiliense is far the most studied species, because of the wide use of its fruit, called pequi, in central Brazil. $C$. brasiliense fruits are highly nutritious and very used in the preparation of juices and liquors; both the fruits and the leaves are used for therapeutic purposes, e.g. in the treatment of colds, coughs and bronchitis; the seeds are used in the manufacture of soaps and as aphrodisiac, and the wood, sturdy and durable, is employed in construction and shipbuilding (Prance, 1990; Araujo, 1995). C. brasiliense wood is also used in the manufacture of fences, due to its durability and resistance to deterioration (Araújo, 1995).

Prance (1990) reported the flowering of C. brasiliense occuring between September and January. The fruits develop quickly after flowering, being often ripe between the months of January and March (Barradas, 1972). The fruit of $C$. brasiliense is round, green, drupoid, possess diameter of about 10 $\mathrm{cm}$, a persistent calyx with one to four pirenes. The mesocarp is subdivided into external and internal (edible yellow part), involving the endocarp thorny (fine and rigid spines, with 2 to $5 \mathrm{~mm}$ long) with a white almond or seed. The inner mesocarp and endocarp thorny seed constitute the pyrenes (Almeida et al., 1998). The fruit of Caryocar villosum resembles C. brasiliense one, being irregularly shaped with a round, oblong shape with approximately $7-9 \mathrm{~cm}$ diameter. C. villosum fruit has external and internal (edible part), mesocarp, and a thorny endocarp. The seeds are also widely used in cooking for the preparation of dishes and occasionally its oil is extracted from the internal mesocarp (Marx, 1997) for culinary appilcations.

Anthodiscus genus comprises nine species, mainly used as source of wood. No chemical description of compounds from Anthodiscus genus has been found in the literature so far (SciFinder $囚$, CAS, August, 2012). Morphological and anatomical studies have been reported for this species, like the description of buds. In relation to the peduncle and to the receptacle, the richomes are unicellular in Anthodiscus. The calyx consists of five sepals close to each other in a cupuliform calyx. The corolla consists of four or five petals that are basally adnate with the adjoining androecial ring. The petals are narrow at the base and thick at the ends, and the whole corolla is circumscissile at the base and fused at the apex to form caducous calyptra (Dickison, 1990). The androceu is composed of numerous stamens, around 100-280 (Prance \& Silva, 1973). In general the filaments are long, upper petals, and varied in length, presenting bright yellow color and are short and bent on the button. Anatomically, the carpels are modified leaves, forming the ovaries of flowers. In the genus Anthodiscus, numerous carpels are opened in the central cavity of an ovary. Each carpel contains a single ovule attached to the placenta (Dickison, 1990). Polinization is mediated by insects (Prance \& Silva, 1973).

TABLE 1. Species from Caryocar and Anthodiscus genus.

\begin{tabular}{ll}
\hline Caryocar & Anthodiscus \\
\hline Caryocar amygdaliferum Mutis. & Anthodiscus amazonicus Gleason \\
Caryocar amygdaliforme G. Don. & Anthodiscus chocoensis Prance \\
Caryocar brasiliense Camb. & Anthodiscus fragrans Sleumer \\
Caryocar coriaceum Wittm. & Anthodiscus klugii Standl. \\
Caryocar costaricense J. D. Smith & Anthodiscus montanus Gleason \\
Caryocar cuneatum Wittm. & Anthodiscus obovatus Benth. \\
Caryocar dentatum Gleason & Anthodiscus peruanus Baill. \\
Caryocar edule Casar & Anthodiscus pilosus Ducke \\
Caryocar glabrum (Aubl.) Pers & Anthodiscus trifoliatus G. Mey. \\
Caryocar gracile Wittm & \\
Caryocar harlingii Prance & \\
Caryocar microcarpum Ducke & \\
Caryocar montanum Prance & \\
Caryocar nuciferum L & \\
Caryocar pallidum A. C. Smith & \\
Caryocar villosum Pers. & \\
\hline
\end{tabular}

Rev. Bras. PI. Med., Campinas, v.15, n.2, p.293-308, 2013. 
Species belonging to Caryocar and Anthodiscus genera are listed in Table 1.

\section{Chemical constituents}

The fruits of Caryocar species are primarily a source of vegetal oils. These oils are used in the cosmetic industry, for illumination and lubrication (Araújo, 1995). Both the pulp of the fruit and the oil obtained from the pulp present high concentration of lipids.

Several studies were conducted to evaluate the lipid composition of the oils and high incidence of unsaturated fatty acids has been found. Pulp of $C$. brasiliense (pequi) fruit presents an intensive aroma, being rich in vitamins, lipids and proteins. This part of the fruit is generally cooked with rice and chicken and also used in the manufacture of sweets and liqueurs. The lipid content of pequi fruit was found to be high $(51.51 \%)$. This fruit also contains proteins $(25.27 \%)$, carbohydrates $(8.33 \%)$, fibers $(2.2 \%)$, low water contents and high amounts of minerals. Contents of dietary fiber in the pulp is higher $(10.02 \%)$ in comparison with the almond, showing also lipids $(33.40 \%)$, carbohydrates $(11.45 \%)$, and proteins $(3.00 \%)$ besides a high water content $(41.50 \%)$ (Lima et al., 2007).

Both pulp and almonds of $C$. brasiliense have high quantities of oil that reaches approximately $30 \%$ of the composition of each of these parts. This high amount of oil places $C$. brasiliense fruit as a potential raw material for the production of esters and acids to be used in biodiesel production. The flour obtained from external mesocarp of pequi presents high amount of starch that can be used as feedstock in the production of ethanol. The chemical characterization of flour from pequi pulp showed the following levels: starch $27.70 \%$, proteins $21.38 \%$, fibers $19.70 \%$, ashes $3.82 \%$, lipides $3.60 \%$; moisture in this part reaches $16.97 \%$. The almond contains mainly proteins $(64.41 \%)$ and moisture $(16.50 \%)$. As minor components, there were detected $9.88 \%$ of starch, $8.76 \%$ of ashes, 6.72 of fibers, and $6.01 \%$ of lipids (Macedo et al., 2011).

Fatty acids of $C$. brasiliense pulp (Figure 1) were quantified by high performance liquid chromatography (HPLC), gas chromatography coupled to mass spectrometry (GC-MS) and liquid chromatography coupled to electrospray ionisation mass spectrometry (LC-ESI-MS/MS) being found oleic $(1,48.71 \%)$, palmitic $(2,44.28 \%)$, linoleic $(3$, $4.43 \%)$ and stearic $(4,2.58 \%)$ acids (Segall et al., 2006). Lima et al. (2007) reported a prevalence of unsaturated fatty acids in the pulp of the fruit $(61.35 \%)$ and in the almond $(52.17 \%)$. Compound 1 is the major component present in the pulp, reaching a concentration of $55.87 \%$, followed by $2(35.17 \%)$. In the almond of pequi there is predominance of 1 and 2 acids (43.59\% and $43.76 \%$ respectively) and, in minor amounts, compound 3 (5.51\%), 4 (2.04\%), palmitoleic $(5,1.23 \%)$ acids are also present. Fatty acids from pequi pulp oil were also evaluated by gas chromatography (GC). The major fatty acids found were acids $1(54.28 \%)$ and $2(41.78 \%)$, while minor amounts of $3(1.36 \%), 5(0.67 \%)$, linolenic $(6,0.51 \%)$, stearic $(7,1.28 \%)$, and araquidic (8, $0.12 \%$ ) acids were also detected (Miranda-Vilela et al., 2009a).

In another study, C brasiliense (pequi) oil was analyzed by GC to determine fatty acids composition. The fatty acids found were 1 (53.9\%),

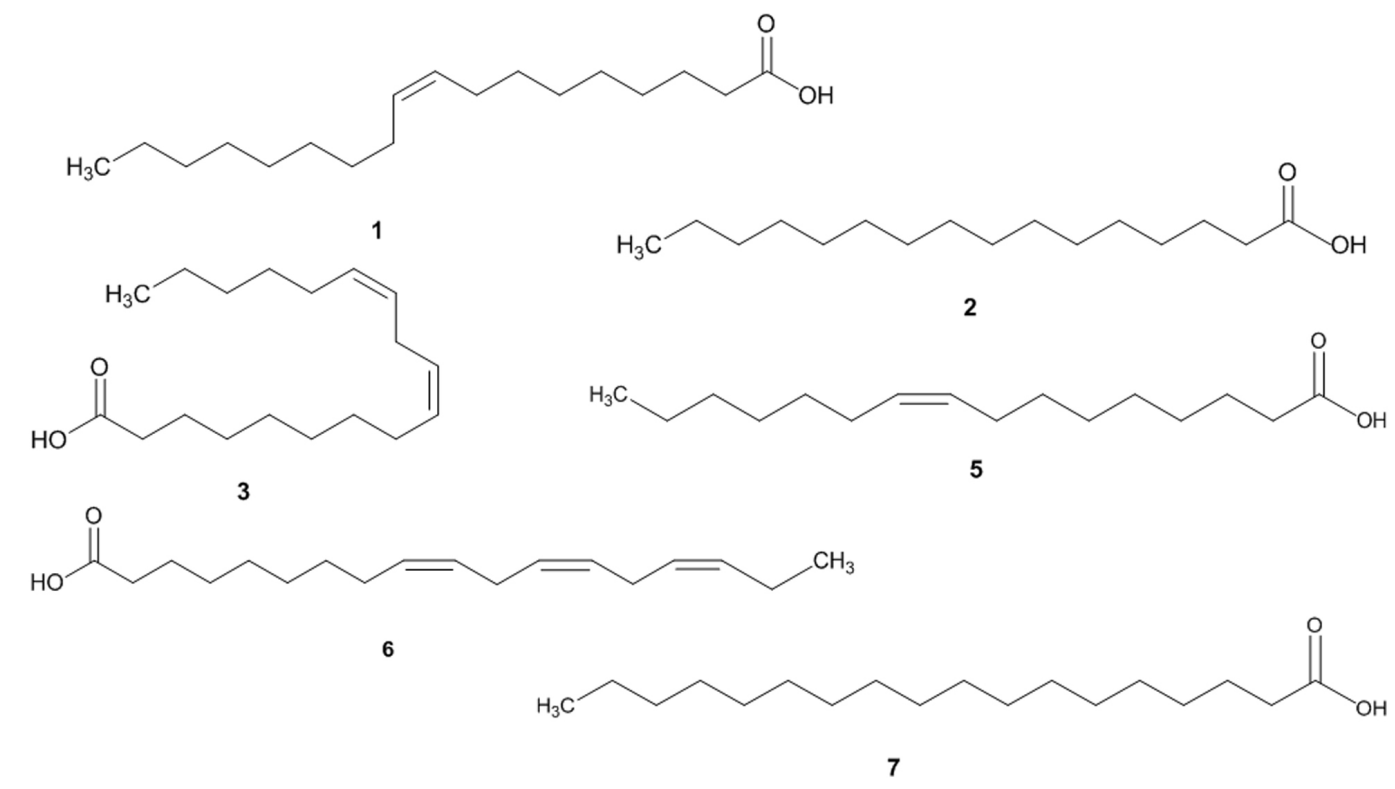

FIGURE 1. Structures of some fatty acids found in C. brasiliense. 
$2(40.2 \%), 7(2.3 \%), 5(1.4 \%), 3(1 \%), 6$ (0.7\%), and $8(0.2 \%)$ (Facioli \& Gonçalvez, 1998).

Fatty acids profile in $C$. brasiliense has been widely studied and, despite of some deviations, possible caused by seasonal variations, acids 1 and $\mathbf{2}$ were consistently detected as the very major components of the oil in most studies. The presence of high amounts of oleic acid (1), known as an essential omega- 9 fatty acid, is very interesting. Oleic acid participates of the human metabolism, playing a key role in the synthesis of hormones, being one of the predominant fatty acids recommended in diets aiming at prevention of heart diseases (Lorgeril \& Salen, 2006; Berry et al., 1991). Oleic acid (1) is also reported to possess several biological activities like prevention of cardiac diseases, lowering of blood pressure and cholesterol reduction (Navarro-Tito et al., 2010; Pontes-Arruda, 2009; Hanna et al., 2009; Stein et al., 2008, Terés et al., 2008). One of these studies demonstrated that the hypothensive effect of olive oil is caused by high levels of oleic acid present in this oil $(70-80 \%)$, indicating that the intake of olive oil increases levels of compound $\mathbf{1}$ in the membrane, lowering blood pressure (Terés et al., 2008).

In C. coriaceum fruit, the fatty acids 1 (56.34\%), 2 (27.63\%), 3 (5.20\%) and 6 (4.42\%) were detected by GC analysis (Lima et al., 1981).

Among the fatty acids detected in the pulp of fruit of C. villosum, $1(33.50 \%), 2(9.50 \%), 4$ $(0.59 \%), 3(0.52 \%)$, and $5(0.10 \%)$ were the major components (Marx et al., 1997).

Qualitative and quantitative comparison of fatty acids found in C. brasiliense, $C$. villosum and C. coriaceum can be found in Table 2 .

While fatty acids have been reported for three species of the genus Caryocar, the composition of triglycerides has been reported only for $C$. brasiliense in two different studies. In the first one, triglycerides contents in $C$. brasiliense pulp were quantified by HPLC, GC-MS and LC-ESI-MS/MS, indicating the presence of POO (palmitoyl dioleoyl glycerol, 9, 46.6\%), POP (dipalmitoyl oleoyl glycerol, 10, 45.2\%), OOO (trioleoyl glycerol, 11, 5.6\%) and OOS (dioleoyl stearoyl glycerol, 12, 0.52\%) (Segall et al., 2006). In another study, C. brasiliense oil was analyzed by GC to determine triglycerides composition indicating the presence of POP (10, $27.6 \%)$, POO (9, 22.9\%), POS (palmitoyl oleoyl glycerol, 13, 18.2\%), SOO (stearoyl dioleoyl, 14, $9.1 \%$ ), SOS (distearoyl oleoyl glycerol, $15,8.7 \%$ ) OOO (11, 5.4\%), LOO (linoleoyl dioleoyl glycerol, 16, 3.8\%), POL (palmitoyl oleoyl linoleoyl glicerol, 17, $2.7 \%$ ) and PPS (dipalmitoyl stearoyl, 18, $0.3 \%$ ) (Facioli \& Gonçalvez, 1998). Some of the differences found can be related to the different procedures used in the oils extraction. Facioli and Gonçalvez (1998) cooked the fruits in water and evaluated the oil obtained while Segal et al. (2006) extracted the oil directly from the dried fruits.

For two species, C. brasiliense and $C$. villosum, phytochemical studies reported the presence of carotenoids in fruit pulps, an interesting fact since these fruits are edible and carotenoids are precursors of vitamin A, possess antioxidant activity, and are associated with reduction of cancer and cardiovascular diseases risk (Bender, 2005).

Ramos et al. (2001) carried out an evaluation of pro-vitamin A capacity of pequi fruit. Carotenoids were characterized in order to evaluate losses of nutritional factors under conventional cooking of pequi pulp with rice. The carotenoids extracted from pequi pulp, raw or cooked, were identified as $\zeta$-carotene (19), $\beta$-carotene (20), $\beta$-cryptoxanthin (21), cryptoflavin (22), anteraxanthin (23), zeaxanthin (24) and mutatoxantin (25). The contents of carotenoids found were 231.09 and $154.5 \mu \mathrm{g} / \mathrm{g}$ for raw and cooked pulp, respectively.

It was noticed that, from the carotenoids found in the raw pulp of $C$. brasiliense, 23 was present in higher concentration (40.54\%), followed by 24

TABLE 2. Percentual compositon of fatty acids in pulp and almond of $C$. brasiliense, $C$. villosum and $C$. coriaceum

\begin{tabular}{|c|c|c|c|c|c|c|c|}
\hline \multirow[b]{2}{*}{ Fatty acids } & \multicolumn{5}{|c|}{ C. brasiliense } & \multirow{2}{*}{$\begin{array}{l}\text { C. villosum } \\
\text { Pulp (\%) }\end{array}$} & \multirow{2}{*}{$\frac{\text { C. coriaceum }}{\text { Pulp (\%) }}$} \\
\hline & Pulp (\%) ${ }^{1}$ & Almond $(\%)^{1}$ & Pulp (\%) & Pulp (\%) & Pulp (\%) & & \\
\hline Araquidic & 0.23 & 0.20 & $\mathrm{Nr}$ & 0.2 & 0.2 & $\mathrm{nr}$ & $\mathrm{nr}$ \\
\hline Linoleic & 1.53 & 5.51 & 4.43 & 1 & 1.36 & 0.52 & 5.20 \\
\hline Linolenic & $\mathrm{nr}$ & $\mathrm{Nr}$ & $\mathrm{Nr}$ & 0.7 & 0.51 & $\mathrm{nr}$ & $\mathrm{nr}$ \\
\hline Oleic & 55.87 & 43.59 & 48.71 & 53.9 & 54.28 & 29.50 & 56.34 \\
\hline Palmitic & 35.17 & 43.76 & 44.28 & 40.2 & 41.78 & 33.50 & 27.63 \\
\hline Palmitoleic & 1.03 & 1.23 & $\mathrm{Nr}$ & 1.4 & 0.67 & 0.10 & $\mathrm{nr}$ \\
\hline Stearic & 2.25 & 2.04 & 2.58 & 2.3 & 1.28 & 0.59 & 4.42 \\
\hline
\end{tabular}

${ }^{1}$ Lima et al., 2007; ${ }^{2}$ Segall et al., 2006; ${ }^{3}$ Facioli and Gonçalvez, 1998; ${ }^{4}$ Miranda-Vilela et al., 2009; ${ }^{5}$ Marx et al., 1997, ${ }^{6}$ Lima et al., 1981. nr: not reported in the species 
(34.24\%), 22 (7.70\%), 20 (6.35\%), $\beta$-cryptoxanthin (26, 5.25\%), $19(4.05 \%)$, and $25(1.87 \%)$. After the conventional cooking it was observed a different concentration of these carotenoids: $24(51.75 \%)$, $23(20.30 \%), 22(8.22 \%), 20$ (7.90\%), 19 (5.30\%), $21(5.18 \%)$, and $25(1.35 \%)$. The carotenoids 20, 22 and 26 presented activities as vitamin "A" precursors and $\mathbf{2 0}$ was found to be the principal responsible for pro-vitamin "A" activity in all samples analyzed. It was noticed that after conventional cooking, loss of carotenoids in pequi pulp occurred on approximately $30.25 \%$, corresponding to the average loss of $12.12 \%$ in vitamin "A" level (Ramos et al., 2001). Structure of the major carotenoids isoladed from $C$. brasiliense are shown in Figure 2.

The carotenoids contents of $C$. brasiliense pulp were also characterized by diodo array detector - high performance liquid chromatography coupled to mass spectrometry(HPLC-DAD-MS) and ultravioletvisible (UV-Vis) spectrophotometry technique as $\mathbf{2 4}$, violaxanthin (27), lutein (28), together with small quantities of 20, 21 and neoxanthin (29) (AzevedoMeleiro et al., 2004).

C. villosum has shown to be a good source of the carotenoids $\mathbf{2 0}$, and $\mathbf{2 1}$, besides presenting small quantities of 19 , cis- $\beta$-cryptoxanthin (30), and $\alpha$-carotene (31) (Godoy, 1993). In other study, C. villosum pulp showed presence pro-vitamins in its composition, such as trans- $\alpha$-carotene (32), 13 -cis- $\beta$-carotene (33), trans$\beta$-carotene (34), neocryptoxanthin (35) and trans$\beta$-cryptoxanthin (36) (Godoy \& Rodriguez-Amaya, 1994).

Analysis by GC-MS of C. brasiliense seeds oil presented ethyl hexanoate (37) ester as the major compound (70.9 - 91.0\%) (Passos et al., 2003). GC-MS was also used to identify several volatile constituents of $C$. brasiliense fruit pulp. The major compound found was $37(52.9 \%)$ followed by minor quantities of 3 -methylvaleric acid $(38,6.0 \%)$, ethyl octanoate $(39,4.6 \%)$, tetrahydrofurfuralcohol $(\mathbf{4 0}$, $4.3 \%)$, ethyl butanoate $(\mathbf{4 1}, 4.1 \%)$, butyl palmitate $(42,3.7 \%)$ and isobutyl stearate $(43,2.6 \%)$ (Maia et al., 2008) (Figure 3).

Ethanol extract from the leaves of $C$. brasiliense showed presence of friedelin (44), friedelanol (45), and oleanolic acid (46) in its composition, as well as $\beta$-amyrin (47), $\beta$-sitosterol (48), stigmasterol (49) and ellagic acid (50) after<smiles>CC(C)=C(C)C(/C=C/C(C)=C/C=C/C(C)=C/C=C/C=C(C)/C=C/C=C(C)/C=C/C1=C(C)CCCC1(C)C)C(C)(C)C</smiles>

20<smiles>CC1=C(/C=C/C(C)=C/C=C/C(C)=C/C=C/C=C(C)/C=C/C=C(C)/C=C/C2=C(C)C[C@@H](O)CC2(C)C)C(C)(C)CCC1</smiles><smiles>C[C]1CCC(C)=C1/C=C(C)/C=C/C=C(C)/C=C/C=C/C=C(C)/C=C/C=C(\C)C1C=C2C(C)(C)CC(O)CC2(C)O1</smiles>

22<smiles>CC1=C(/C=C/C(C)=C/C=C/C(C)=C/C=C/C=C(C)/C=C/C=C(C)/C=C/C23OC2(C)C[C@H](O)CC3(C)C)C(C)(C)C[C@H](O)C1</smiles><smiles>CC1=C(/C=C/C(C)=C/C=C/C(C)=C/C=C/C=C(C)/C=C/C=C(C)/C=C/C2=C(C)C(C)CC(O)C2)C(C)(C)CC(O)C1</smiles>

23

24<smiles>CC(/C=C/C=C(C)/C=C/C12O[C@@]1(C)CC(O)CC2(C)C)=C\C=C\C=C(C)\C=C\C=C(C)\C=C\[C@@]12O[C@]1(C)CC(O)CC2(C)C</smiles>

27<smiles>CC1=C[C@@H](O)CC(C)(C)[C]1/C=C/C(C)=C/C=C/C(C)=C/C=C/C=C(C)/C=C/C=C(C)/C=C/C1=C(C)C[C@@H](O)CC1(C)C</smiles>

FIGURE 2. Structures of carotenoids found in C. brasiliense fruit pulp. 


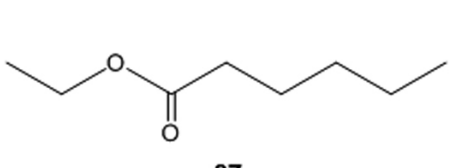

37

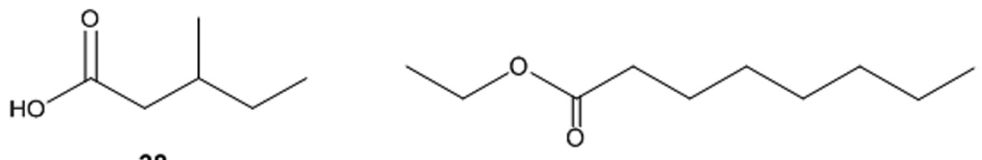

38<smiles>CCCC(=O)OCC</smiles>

41

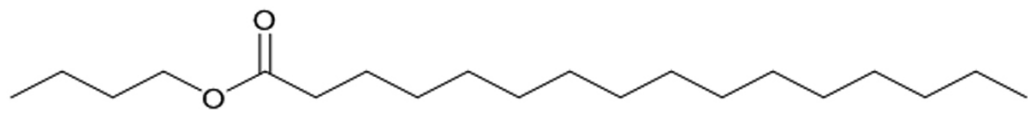

42

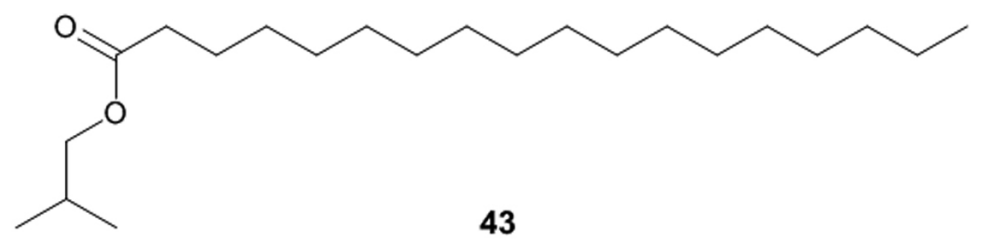

FIGURE 3. Structures of some volatiles constituents of $C$. brasiliense fruit pulp.

hydrolysis of the extract (Oliveira et al., 1968). Also in the ethanolic extract, quinic (51) and gallic (52) acids, quercetin (53) and quercetin 3-O-arabinose (54) were identified by LC-ESI-MS/MS (Roesler et al., 2008).

Phytochemical study of the epicarp and external mesocarp of $C$. brasiliense fruit (ethanolic extract) led to the isolation of several compounds: $2,48,49,52$, ethyl gallate (55), 5-hydroxyfurfural (56), methyl shikimate (57), and mixtures of $\beta$-Dfructopyranose (58) and $\beta$-D-fructofuranose (59), $\alpha-(60)$ and $\beta$-D-glucose (61), and lupeol (62) (Figure 4). Compound $\mathbf{5 5}$ was found to be the major constituent, being present as $14 \%$ of the crude ethanolic extract, but this compound is the reaction product of esterification of $\mathbf{5 2}$ during extraction, which means gallic acid is the major component of this extract (Ascari et al., 2010).

C. brasiliense fruit presents $209 \mathrm{mg}$ of total phenolics in $100 \mathrm{~g}$ of the pulp; this value is higher than those found in the majority of pulp of fruits consumed in Brazil, such as açaí $(136.8 \mathrm{mg} / 100 \mathrm{~g})$, soursop $(84.3 \mathrm{mg} / 100 \mathrm{~g})$ and guava $(83.1 \mathrm{mg} / 100 \mathrm{~g})$. The levels of phenolics and carotenoids are reduced in pequi kernel in relation to contents found in the pulp (Lima et al., 2007).

A study to assess the composition of $C$. villosum fruit pulp showed the presence of several compounds that were quantified in relation to the pulp. In this way, there were quantified the carbohydrates glucose $(63,0.92 \%)$, sucrose $(64$, $0.79 \%)$, and fructose $(65,0.26 \%)$ and the minerals Ca $(83.0 \%), \mathrm{Mg}(52.0 \%), \mathrm{P}(41.0)$, Se $(0.70 \%)$, Fe $(0.64), \mathrm{Zn}(0.52 \%)$ and $\mathrm{Mn}(0.32 \%)$. Steroids present in C. villosum fruit pulp were $49(80.20 \%)$ and $48(29.70 \%)$; free amino acids found were aspargine $(66,18.4 \%)$, alanine $(67,17.8 \%)$, leucine $(68,14.62 \%)$, valine $(69,11.80 \%)$, glutamine $(\mathbf{7 0}$, $10.36 \%), \gamma$-aminobutyric acid $(\mathbf{7 1}, 5.84 \%)$; biogenic minerals amines o-phosphoethanolamine (72, $3.04 \%)$ and taurine $(73,2.52 \%)$ were also detected. In the same study, the major volatile compounds identified were the (e)-nerolidol $(\mathbf{7 4}, 19.75 \%)$, 2-heptanone (75, 19.30\%), $\beta$-bisabolene (76, 18.7\%) and furfural $(77,14.62 \%)$ (Marx et al., 1997).

In the leaves of $C$. microcarpum there were found large quantities of gallotannin, 50, 52 and methyl gallate (78) along with glycosides of 46 and its hydroxylated derivatives $2 \beta$-hydroxyoleanolic acid (79), hederagenin (80) and bayogenin (81) (Kawanishi et al., 1986) (Figure 5).

Studies carried on with fruits, stem barks and skin of the species C. villosum and C. glabrum led to the isolation, by the first time, of triterpene saponins, phenolic glucosides and polar dihydroisocoumarin compounds in those species. The isolated saponins showed amphiphilic behavior and ability to form complexes with steroids, membrane proteins and phospholipids. This behavior determined a number of biological properties for these substances, such as hemolytic activity, cytotoxic and molluscide (Schenkel, 2003).

A combination of silica gel, reversed phase column chromatography and semi-preparative HPLC of a fraction from the methanolic extract of C. villosum stem barks also led to the isolation of triterpene saponins, five of them being reported for the first time: 
<smiles>CC[C@H](CC[C@H](C)[C@H]1CC[C@H]2C3CC=C4C[C@@H](O)CC[C@]4(C)C3CC[C@@]21C)C(C)C</smiles>

48<smiles>CCOC(=O)c1cc(O)c(O)c(O)c1</smiles>

55

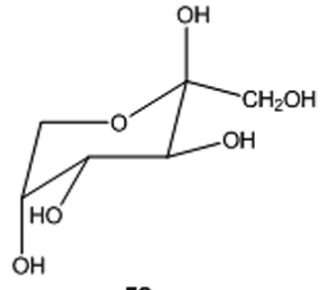

58<smiles>O=Cc1ccc(CO)o1</smiles>

56

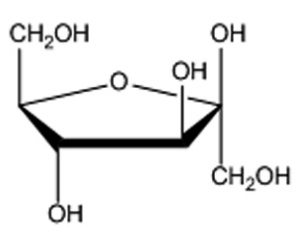

59<smiles>O=C(O)c1cc(O)c(O)c(O)c1</smiles>

52

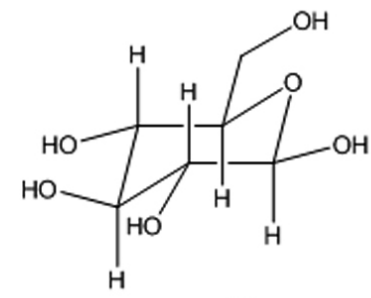

61<smiles>C=C(C)[C@H]1CC[C@]2(C)CC[C@]3(C)C(CCC4[C@@]5(C)CC[C@H](O)C(C)(C)[C@H]5CC[C@]43C)C12</smiles>

62

FIGURE 4. Constituents of mesocarp and external epicarp of $C$. brasiliense fruits.<smiles>O=c1oc2c(O)c(O)cc3c(=O)oc4c(O)c(O)cc1c4c23</smiles>

50

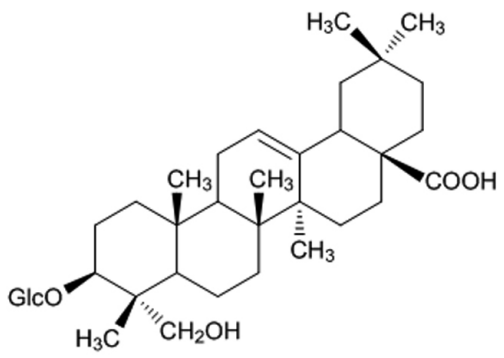

80<smiles>COC(=O)c1cc(O)c(O)c(O)c1</smiles>

78

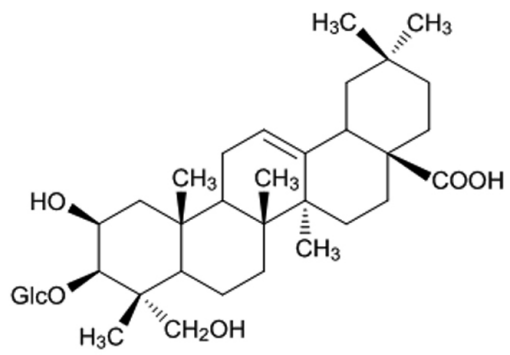

81

FIGURE 5. Constituents of C. microcarpum leaves. 
3-O- $\alpha$-L-rhamnopyranosyl- $(1 \rightarrow 3)-$

$\beta$-D-galactopyranosyl- $(1 \rightarrow 3)-\beta$-D-

glucuronopyranosylhederagenin (82), 3-O- $\alpha$

-L-rhamnopyranosyl-(1 $\rightarrow 3)$ - $\beta$-D-galactopyranosyl-

$(1 \rightarrow 3)-\beta$-D-glucuronopyranosylbayogenin

(83), 3-O- $\alpha$-L-rhamnopyranosyl-(1 $\rightarrow 3)$ -

$\beta$-D-galactopyranosyl-( $1 \rightarrow 3)-\beta$-D-

glucuronopyranosylhederagenin-28-O-

$\beta$-D-glucopyranosil ester (84), 3-O- $\alpha$-L-

rhamnopyranosyl-(1 $\rightarrow 3)-\beta$-D-galactopyranosyl-

$(1 \rightarrow 3)-\beta$-D-glucuronopyranosylbayogenin-28-

$O-\beta$-D-glucopyranosil ester (85) e 3-O- $\alpha$-Lrhamnopyranosyl-(1 $\rightarrow 3)-\beta$-D-galactopyranosyl$(1 \rightarrow 3)-\beta$-D-glucuronopyranosylhederagenin-28-O-

[2-O-galloyl- $\beta$-D-glucopyranosyl ester (86) (Figure

$6)$. Through acid hydrolysis it has been possible

to identify two aglicones, $\mathbf{8 0}$ and $\mathbf{8 1}$ (Magid et al., 2006a).

The same group related the isolation of seven new phenolic glycosides (Figure
7). The compounds 3-O-methyl-4'-(3"-Oacetyl)- $\alpha$-L-rhamnopyranosylellagic acid (87) and 3-O-methyl-4'-(4"-O-acetyl)- $\alpha-L-$ rhamnopyranosylellagic acid (88) were isolated from the methanolic extract of $C$. villosum stem barks and 1-O-3', $4^{\prime}, 5^{\prime}$-trimethoxyphenyl(2,3-di-O-galloyl)- $\beta$-D-glucopyranoside (89), $1-O-3^{\prime}, 4^{\prime}, 5^{\prime}$-trimethoxyphenyl-(2-O-galloyl)- $\beta$-Dglucopyranoside (90), 1-O-3',4',5'-trimethoxyphenyl-(3-O-galloyl-6-O-sulphate)- $\beta$-Dglucopyranoside (91), 1-O-3',4'-dimethoxy-phenyl(2-O-galloyl-6-O-sulphate)- $\beta$-D-glucopyranoside (92) and 1,5-di-O-galloyl- $\beta$-D-hamamelofuranose (93) were isolated from the aqueous extract of stem bark of C. glabrum (Magid et al., 2008). Phytochemical study of the methanolic extract from stem barks of $C$. villosum and $C$. glabrum led to isolation of 15 known compounds: 50, 3-O-methylellagicacid-4'-(2"'-O-acetyl)-O- $\alpha$-Lrhamnopyranoside (94), 3-O-methylellagic acid-

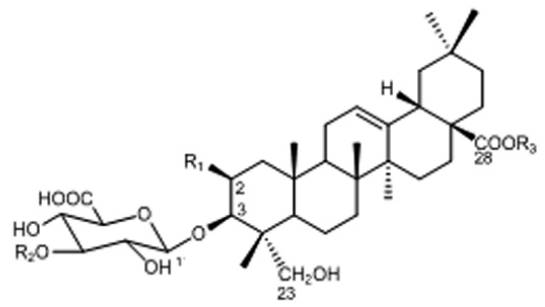

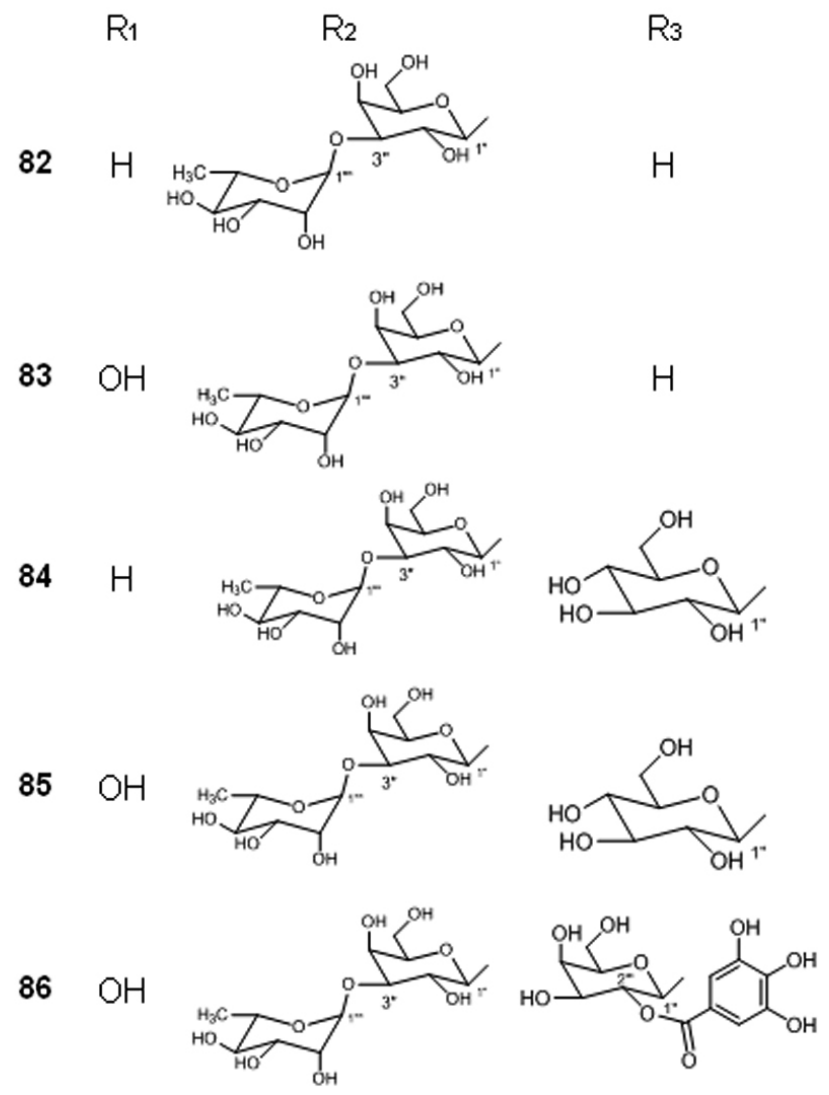

FIGURE 6. Structures of some triterpenoid present in the stem bark of C. villosum. 


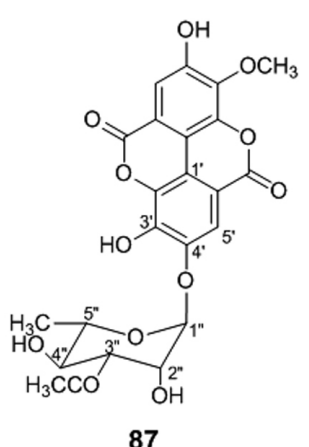

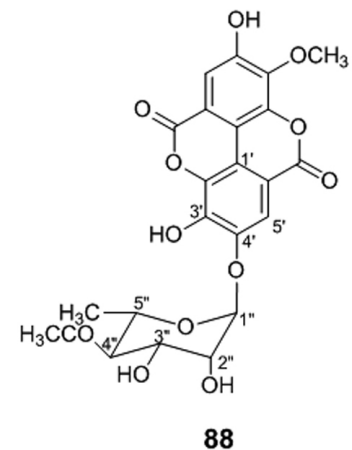

88

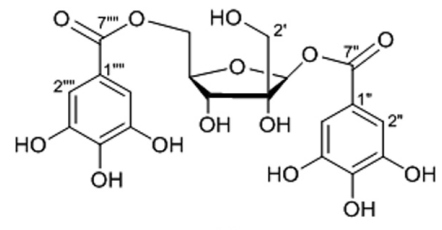

93

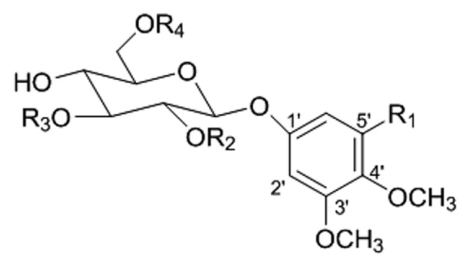

$89 \mathrm{R}_{1}=\mathrm{OCH}_{3}, \mathrm{R}_{2}=\mathrm{R}_{3}=$ Galloyl, $\mathrm{R}_{4}=\mathrm{H}$

$90 \mathrm{R}_{1}=\mathrm{OCH}_{3}, \mathrm{R}_{2}=$ Galloyl $\mathrm{R}_{3}=\mathrm{R}_{4}=\mathrm{H}$

$91 \mathrm{R}_{1}=\mathrm{OCH}_{3}, \mathrm{R}_{2}=\mathrm{H}, \mathrm{R}_{3}=$ Galloyl, $\mathrm{R}_{4}=\mathrm{SO}_{3} \mathrm{Na}$

$92 \mathrm{R}_{1}=\mathrm{H}, \mathrm{R}_{2}=$ Galloyl, $\mathrm{R}_{3}=\mathrm{H}, \mathrm{R}_{4}=\mathrm{SO}_{3} \mathrm{Na}$

FIGURE 7. Structure of some phenolic glycosides present in the stem barks of $C$. villosum and C. glabrum.

42 -O- $\alpha$-L-rhamnopyranoside (95), 5-O-galloylD-hamamelofuranose (96), 22 -O-galloyl-Dhamamelofuranose (97), 22 ,5-di-O-galloyl-Dhamamelofuranose (98), $22,3,5$-tri-O-galloyl-Dhamamelofuranose (99), 1,22 ,3,5-tetra-O-galloyl$\beta$-D-hamamelofuranose (100), 1,2,3,4,6-penta-Ogalloyl- $\beta$-D-glucose (101), corilagin (102), tercatain (103), chebulagic acid (104), putranjivain $A(105)$, nikoenoside (106) e 1-O-3,4,5-trimethoxyphenyl- $\beta$ D-glucopyranoside (107) (Magid et al., 2008).

From the methanolic extract of C. villosum fruits peels, 24 triterpene saponins were isolated, 14 of them being new (Figure 8) and identified as 3-O- $\beta$-Dxylopyranosyl-( $1 \rightarrow 3)-\beta$-D-galactopyranosyl$(1 \rightarrow 3)-\beta-D$-glucopyranosylhederagenin-28$O-b$-D-glucopyranosyl ester (108), 3-O- $\beta$-Dxylopyranosyl-( $1 \rightarrow 3)$ - $\beta$-D-galactopyranosyl$(1 \rightarrow 3)-\beta-D$-glucopyranosylbayogenin-28-O$\beta$-D-glucopyranosyl ester (109), 3-O- $\beta$-Dgalactopyranosyl-( $1 \rightarrow 3)-\beta$-D-galactopyranosyl$(1 \rightarrow 3)-\beta$-D-glucopyranosylhederagenin-28$O-\beta$-D-glucopyranosyl ester (110), 3-O- $\beta$-Dgalactopyranosyl-( $1 \rightarrow 3)-\beta-D-$ galactopyranosyl$(1 \rightarrow 3)-\beta$-D-glucopyranosylbayogenin28-O- $\beta$-D-glucopyranosyl ester (111), 3-O- $\beta$-D-xylopyranosyl- $(1 \rightarrow 3)-\beta$-Dgalactopyranosyl-( $1 \rightarrow 3)-\beta-D$-galactopyranosyl$(1 \rightarrow 3)-\beta-D-g l u c o p y r a n o s y l b a y o g e n i n-28-O-$ $\beta$-D-glucopyranosyl ester (112), 3-O- $\beta$-Dxylopyranosyl-(1 $\rightarrow 3)-\beta$-D-galactopyranosyl$(1 \rightarrow 3)-\beta-D-g a l a c t o p y r a n o s y l-(1 \rightarrow 4)-\beta-D-$ galactopyranosyl-(1 $\rightarrow 3)-\beta-D-$ glucopyranosyl hederagenin-28-O- $\beta$-D-glucopyranosyl ester (113), 3-O- $\beta$-D-xylopyranosyl$(1 \rightarrow 3)-\beta-D-g a l a c t o p y r a n o s y l-(1 \rightarrow 3)-\beta-D-$ galactopyranosyl-( $1 \rightarrow 4)-\beta$-D-galactopyranosyl$(1 \rightarrow 3)-\beta-D-g l u c o p y r a n o s y l b a y o g e n i n-$ 28-O- $\beta$-D-glucopyranosyl ester (114), $3-O-\beta$-D-xylopyranosyl- $(1 \rightarrow 3)-\beta$-Dgalactopyranosyl-( $1 \rightarrow 3)-\beta$-D-galactopyranosyl$(1 \rightarrow 4)-\beta$-D-galactopyranosyl-( $1 \rightarrow 3)$ $\beta$-D-glucopyranosylbayogenin (115), $3-O-\beta-D-g a l a c t o p y r a n o s y l-(1 \rightarrow 3)-\beta-D-$ methylglucopyranosiduronate-2 $\beta$-hydroxyoleanolic acid-28-O- $\beta$-D-glucopyranosyl ester (116),3-O- $\beta$ D-xylopyranosyl-( $1 \rightarrow 3)$ - $\beta$-D-galactopyranosyl$(1 \rightarrow 3)-\beta$-D-glucuronopyranosyl-2 $\beta$ hydroxyoleanolic acid-28-O- $\beta$-D-glucopyranosyl ester (117), 3-O- $\beta$-D-xylopyranosyl$(1 \rightarrow 3)-\beta$-D-galactopyranosyl-(1 $\rightarrow 3)-\beta$-Dmethylglucopyranosiduronate-2 $\beta$-hydroxyoleanolic acid-28-O- $\beta$-D-glucopyranosyl ester (118), 3-O- $\beta$ $D$-xylopyranosyl-(1 $\rightarrow 3)$ - $\beta$-D-galactopyranosyl$(1 \rightarrow 4)-\beta$-D-galactopyranosyl-( $1 \rightarrow 3)-\beta$ - $D$ glucuronopyranosyl-2 $\beta$-hydroxyoleanolic acid (119), 3-O- $\beta-D-x y l o p y r a n o s y l-(1 \rightarrow 3)-\beta-D-$ galactopyranosyl-( $1 \rightarrow 3)-\beta$-D-galactopyranosyl$(1 \rightarrow 4)-\beta$-D-galactopyranosyl-( $1 \rightarrow 3)-\beta$-Dglucuronopyranosyl-2 $\beta$-hydroxyoleanolic acid (120) and 3-O- $\beta$-D-xylopyranosyl- $(1 \rightarrow 3)-\beta-D-$ galactopyranosyl-( $1 \rightarrow 3)-\beta$-D-galactopyranosyl$(1 \rightarrow 4)-\beta$-D-galactopyranosyl- $(1 \rightarrow 3)-\beta$-Dglucuronopyranosyl-2 $\beta$-hydroxyoleanolic acid-28$O-\beta$-D-glucopyranosil ester (121). Acid hydrolysis has been used to identify the aglycons of the unknown saponins showing 80 to be the aglycon of saponins 108, 110 e 113. Compound 81 was identified as the aglicon of saponins 109,111 , 112, 114 and 115; compound 79 showed to be the aglicon present in 116 - 121 (Magid et al., 2006b). C. glabrum was targeted by Magid 


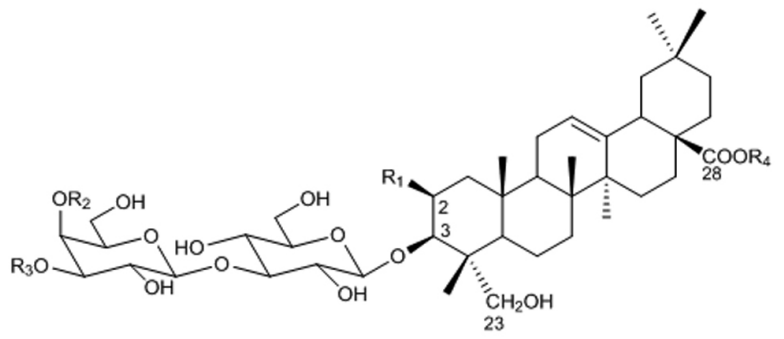

\begin{tabular}{|c|c|c|c|c|}
\hline & $\mathrm{R}_{1}$ & $\mathrm{R}_{2}$ & $\mathrm{R}_{3}$ & $\mathrm{R}_{4}$ \\
\hline 108 & $\mathrm{H}$ & $\mathrm{H}$ & Xyl- & Glc'- \\
\hline 109 & $\mathrm{OH}$ & $\mathrm{H}$ & Xyl- & Glc'- \\
\hline 110 & $\mathrm{H}$ & $\mathrm{H}$ & Gal'- & Glc'- \\
\hline 111 & & $\mathrm{H}$ & Gal'- & Glc'- \\
\hline 112 & $\mathrm{OH}$ & $\mathrm{H}$ & $\begin{array}{l}\text { Xyl-(1 }(1 \rightarrow 3) \text {-Gal"- } \\
(1 \rightarrow 3) \text {-Gall'- }\end{array}$ & Glc'- \\
\hline 113 & $\mathrm{H}$ & $\begin{array}{c}\text { Xyl-(1-3)-Gal"- } \\
\quad(1 \rightarrow 3) \text {-Gal'- }\end{array}$ & $\mathrm{H}$ & Glc'- \\
\hline \multirow{3}{*}{$\begin{array}{l}114 \\
115\end{array}$} & $\mathrm{OH}$ & $\begin{array}{l}\text { Xyl-(1-3)-Gal"- } \\
(1 \rightarrow 3) \text {-Gal'- }\end{array}$ & $\mathrm{H}$ & Glc'- \\
\hline & $\mathrm{OH}$ & 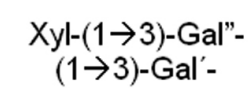 & $\mathrm{H}$ & $\mathrm{H}$ \\
\hline & $R_{1}$ & $\mathrm{R}_{2}$ & $\mathrm{R}_{3}$ & $\mathrm{R}_{4}$ \\
\hline 116 & $-\mathrm{CH}_{3}$ & $\mathrm{H}$ & $\mathrm{H}$ & Glc'- \\
\hline 117 & $\mathrm{H}$ & $\mathrm{H}$ & Xyl- & Glc'- \\
\hline 118 & $-\mathrm{CH}_{3}$ & $\mathrm{H}$ & Xyl- & Glc'- \\
\hline 119 & $\mathrm{H}$ & Xyl-(1 $\rightarrow 3)-G a l '-$ & $\mathrm{H}$ & $\mathrm{H}$ \\
\hline 120 & $\mathrm{H}$ & $\begin{array}{l}\text { Xyl-(1 }(\rightarrow 3)-G a l "- \\
\quad(1 \rightarrow 3)-G a l^{\prime}-\end{array}$ & $\mathrm{H}$ & $\mathrm{H}$ \\
\hline 121 & $\mathrm{H}$ & $\begin{array}{c}\text { Xyl-(1-3)-Gal"- } \\
\quad(1 \rightarrow 3)-G a l '-\end{array}$ & $\mathrm{H}$ & Glc'- \\
\hline
\end{tabular}

FIGURE 8. Structure of some triterpene saponins isolated from C. villosum fruits peels.

and co-workes in some chemical studies. The methanolic extract from pulp of $C$. glabrum fruits was chromatographed by silica gel column and semipreparative reversed phase $\mathrm{HPLC}$ resulting in the isolation of 30 triterpene saponins, being 21 described by the first time (Figure 9): 3-O- $\beta$-D-galactopyranosyl$(1 \rightarrow 3)-\beta-D$-glucopyranosylgypsogenic acid (122), 3-O- $\beta$-D-galactopyranosyl$(1 \rightarrow 3)-\beta$-D-glucopyranosylhederagenin (123), 3-O- $\beta$-D-galactopyranosyl- $(1 \rightarrow 3)$ -
$\beta$-D-glucopyranosylbayogenin (124),

$3-O-\beta$-D-galactopyranosyl- $(1 \rightarrow 3)-$

$\beta$-D-glucopyranosylhederagenin-28$O-\beta-D$-glucopyranosil ester (125), 3 -O- $\beta$-D-galactopyranosyl-( $1 \rightarrow 3)-\beta$-Dglucopyranosylbayogenin-28-O- $\beta$-D-glucopyranosil ester (126), 3-O- $\beta$-D-galactopyranosyl$(1 \rightarrow 3)-\beta$-D-galactopyranosyl- $(1 \rightarrow 3)-\beta$-Dglucopyranosylhederagenin (127), 3-O- $\beta$-Dgalactopyranosyl-( $1 \rightarrow 3)-\beta-D$-galactopyranosyl-

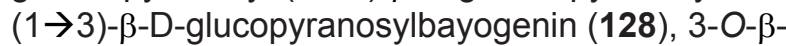

Rev. Bras. PI. Med., Campinas, v.15, n.2, p.293-308, 2013. 
D-xylopyranosyl( $1 \rightarrow 3)-\beta$-D-galactopyranosyl$(1 \rightarrow 3)-\beta$-D-glucopyranosylbayogenin (129), 3-O- $\beta$-D-glucuro-nopyranosyl$2 \beta$-hydroxyoleanolic acid (130), 3-O- $\beta$-Dglucuronopyranosylbayogenin (131), 3-O- $\beta-D-$ methylglucopyranosiduronate-2 $\beta$-hydroxyoleanolic acid (132), 3-O- $\beta$-D-galactopyranosyl- $(1 \rightarrow 3)$ $\beta$-D-glucuronopyranosyl-2 $\beta$-hydroxyoleanolic acid (133), 3-O- $\beta$-D-galactopyranosyl$(1 \rightarrow 3)-\beta-D-$ glucuronopyranosylhederagenin (134), 3-O- $\beta$-D-galactopyranosyl-( $1 \rightarrow 3)$ $\beta$-D-glucuronopyranosylbayogenin (135), 3-O- $\beta$-D-galactopyranosyl- $(1 \rightarrow 3)-\beta$-Dmethylglucopyranosiduronate-2 $\beta$-hydroxyoleanolic acid (136), 3-O- $\beta$-D-galactopyranosyl-(1 $\rightarrow 3)$ $\beta$-D-glucuronopyranosyl-2 $\beta$-hydroxyoleanolic acid-28-O- $\beta$-D-glucopyranosyl ester (137), 3-O- $\beta$-D-galactopyranosyl-( $1 \rightarrow 3)$ $\beta$-D-glucuronopyranosylhederagenin28-O- $\beta$-D-glucopyranosyl ester (138),
3-O- $\beta$-D-galactopyranosyl- $(1 \rightarrow 3)-\beta-D-$ glucuronopyranosylbayogenin-28-O- $\beta$ D-glucopyranosyl ester (139), 3-O- $\beta$-Dgalactopyranosyl- $(1 \rightarrow 3)-\beta-D-m e t h y l g l u c o p y r a n o$ siduronatehederagenin-28-O- $\beta$-D-glucopyranosil ester (140), 3-O- $\beta$-D-galactopyranosyl-( $1 \rightarrow 3)-\beta$-Dgalactopyranosyl-( $1 \rightarrow 3)-\beta$-D-glucuronopyranosyl$2 \beta$-hydroxy oleanolic acid (141) and 3-O- $\beta$-Dgalactopyranosyl-( $1 \rightarrow 3)-\beta$-D-galactopyranosyl$(1 \rightarrow 3)-\beta$-D-glucuronopyranosylhederagenin (142). Some known saponins isolated from methanolic extract from pulp of C. glabrum fruits were identified as bearing oleanolic acid as aglicon: arvenoside $B(143)$, glycoside $F(144)$, glycoside $D$ (145), 3-O- $\beta$-D-galactopyranosyl-(1 $\rightarrow 3)-\beta$-Dmethylglucopyranosiduronate oleanolic acid (146) and glycoside C (147). The other saponins isolated in that study were identified and presented other types of aglicones, such as colchiside 4 (148), 3-O- $\beta$-D-glucuronopyranosylhederagenin

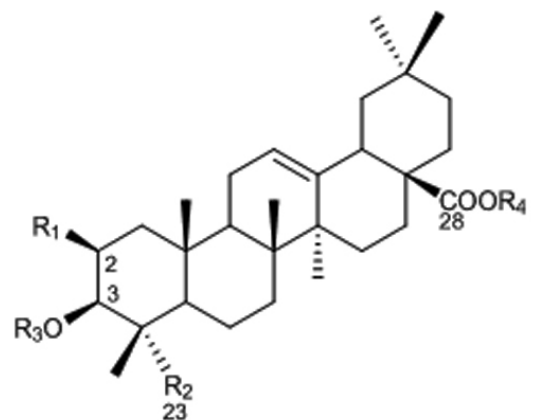

\begin{tabular}{|c|c|c|c|}
\hline 122 & $\begin{array}{l}\mathrm{R}_{1} \\
\mathrm{H}\end{array}$ & $\underset{\mathrm{COOH}}{\mathbf{R}_{2}}$ & $\begin{array}{c}\mathbf{R}_{3} \\
\text { Gal- }(1 \rightarrow 3)-G \mid c-\end{array}$ \\
\hline 123 & $\mathrm{H}$ & $\mathrm{CH}_{2} \mathrm{OH}$ & 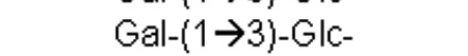 \\
\hline 124 & $\mathrm{OH}$ & $\mathrm{CH}_{2} \mathrm{OH}$ & 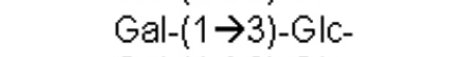 \\
\hline 125 & $\mathrm{H}$ & $\mathrm{CH}_{2} \mathrm{OH}$ & 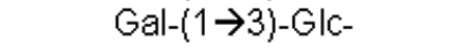 \\
\hline 126 & $\mathrm{OH}$ & $\mathrm{CH}_{2} \mathrm{OH}$ & 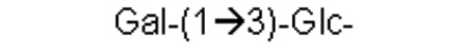 \\
\hline 127 & $\mathrm{H}$ & $\mathrm{CH}_{2} \mathrm{OH}$ & 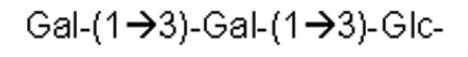 \\
\hline 128 & $\mathrm{OH}$ & $\mathrm{CH}_{2} \mathrm{OH}$ & Gal- $(1 \rightarrow 3)-G a l-(1 \rightarrow 3)-G \mid c-$ \\
\hline 129 & $\mathrm{OH}$ & $\mathrm{CH}_{2} \mathrm{OH}$ & 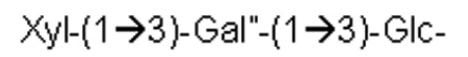 \\
\hline $\begin{array}{l}130 \\
131\end{array}$ & $\begin{array}{l}\mathrm{OH} \\
\mathrm{OH}\end{array}$ & $\begin{array}{c}\mathrm{CH}_{3} \\
\mathrm{CH}_{2} \mathrm{OH}\end{array}$ & $\begin{array}{l}\text { GlCA- } \\
\text { GlCA- }\end{array}$ \\
\hline 132 & $\mathrm{OH}$ & $\mathrm{CH}_{3}$ & 6-O-methyl-GICA- \\
\hline 133 & $\mathrm{OH}$ & $\mathrm{CH}_{3}$ & Gal-(1-3)-GlcA- \\
\hline 134 & $\mathrm{H}$ & $\mathrm{CH}_{2} \mathrm{OH}$ & Gal- $(1 \rightarrow 3)-G \mid c A-$ \\
\hline 135 & $\mathrm{OH}$ & $\mathrm{CH}_{2} \mathrm{OH}$ & Gal- $(1 \rightarrow 3)-G \mid c A-$ \\
\hline 136 & $\mathrm{OH}$ & $\mathrm{CH}_{3}$ & Gal-(1 $\rightarrow 3)-6-O$ methyl-GlcA- \\
\hline 137 & $\mathrm{OH}$ & $\mathrm{CH}_{3}$ & Gal- $(1 \rightarrow 3)-G \mid c A-$ \\
\hline 138 & $\mathrm{H}$ & $\mathrm{CH}_{2} \mathrm{OH}$ & 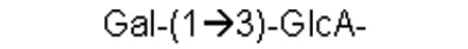 \\
\hline 139 & $\mathrm{OH}$ & $\mathrm{CH}_{2} \mathrm{OH}$ & 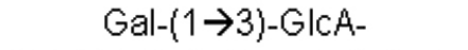 \\
\hline 140 & $\mathrm{H}$ & $\mathrm{CH}_{2} \mathrm{OH}$ & 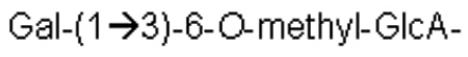 \\
\hline 141 & $\mathrm{OH}$ & $\mathrm{CH}_{3}$ & Gal- $(1 \rightarrow 3)-G a l-(1 \rightarrow 3)-G \mid c A-$ \\
\hline 142 & $\mathrm{H}$ & $\mathrm{CH}_{2} \mathrm{OH}$ & Gal- $(1 \rightarrow 3)-G a l-(1 \rightarrow 3)-G \mid c A-$ \\
\hline
\end{tabular}

FIGURE 9. Structure of some triterpene saponins isolated from C. villosum peel fruits. 
(149), 3-O- $\beta$-D-methylglucopyranosiduronatehede

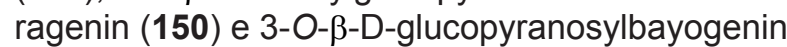
(151). The saponins 130,132, 133, 136, 137 and 141 showed 2 - $\beta$-hydroxyoleanolic acid as aglicon while, in saponin 122, aglicon showed to be gypsogenic acid (Magid et al., 2006c).

From methanolic extract of C. glabrum stem barks, two dihydroisocoumarin glucosides, (3S,4S) 3-( $\beta$-D-glucopyranosyloxymethyl)-3,4dihydro-5,6,7-trihydroxy-4-(4'-hydroxy-3'-methoxyphenyl)-1H-[2]-benzopyran-1-one (152) and (3S,4S) 3-( $\beta$-D-glucopyranosyloxymethyl)-3,4-dihydro-5,6,7trihydroxy-4-(4'-hydroxy-3'-5'-dimethoxyphenyl)$1 H$-[2]-benzopyran-1-one (153) (Figure 10) were isolated by column chromatography in Sephadex LH-20 and RP-18 semipreparative HPLC (Magid et al., 2007).

\section{Biological activities}

The oil of $C$. brasiliense fruits was tested as an antifungal agent against strains of $C$. albicans but it was inactive (Passos et al., 2003). The crude ethanolic extract from barks and leaves of $C$. brasiliense presented toxic activity against Biomphalaria glabrata, intermediate host of Schistosoma mansoni, the causative agent of schistosomiasis. At the concentration of $100 \mathrm{ppm}$, both ethanolic extracts of barks and leaves showed high toxicity against B. glabrata, reaching $90 \%$ of mortality after 48 hours. At a lower concentration (50 ppm) a drastic decrease of toxicity was observed, leaves presenting $20 \%$ of mortality rate; barks extract killed $10 \%$ of the parasites after 48 hours (Bezerra et al., 2002).

The ethanolic extract of $C$. brasiliense barks presented a significant effect on the parasitemia caused by Trypanosoma cruzi $Y$ strain, at the concentration of $400 \mathrm{ppm}$, reducing the number of circulating parasites in the blood. However, total mortality was not achieved (Herzog-Soares et al., 2002).

By the other hand, parasitemia of ethanolic extract from $C$. brasiliense barks was evaluated on mice inoculated with $T$. cruzi $Y$ strain, in the acute phase of infection. A significant reduction of parasitemia was observed at the concentration of $400 \mathrm{ppm}$ and only eigh days after infection. The percentage of growth inhibition corresponded to $52.9 \%$ when compared with the control (HerzogSoares et al., 2006).

The effect of methanolic and ethanolic extracts, obtained from leaves and floral buds, external and internal mesocarps of $C$. brasiliense fruits was tested against phytopathogenic fungi species Botrytis cinerea, Colletotrichum truncatum and Fusarium oxysporum. It was observed a stimulus in the fungal growth caused by the extracts (Marques et al., 2002).

Hydroalcoholic extract from C. brasiliense leaves inhibited the proliferation of promastigota form of $L$. amazonensis, an effect significantly superior to the effect shown by glucantime, a drug used for leismaniasis treatment. This extract inhibited growth of several bacteria tested in the same study. The best antibacterial activity was observed against Pseudomonas aeruginosa $\left(1.5 \times 10^{3} \mu \mathrm{g} / \mathrm{mL}\right)$ and Staphylococcus aureus $\left(2.0 \times 10^{3} \mu \mathrm{g} / \mathrm{mL}\right)$ (PaulaJunior et al., 2006).

The antioxidant activity of hydroalcoholic extract of $C$. brasiliense leaves was evaluated by DPPH method showing a potent antioxidant activity of extract. It was noticed that, at the concentration of $1 \times 10^{3} \mu \mathrm{g} / \mathrm{mL}$, the extract showed activity similar to that presented by vitamin $C$ and rutin. However, no differences between their $\mathrm{EC}_{50}$ values were found (Paula-Junior et al., 2006).

The crude extract and fractions obtained from the epicarp and mesocarp of $C$. brasiliense were tested for their antioxidant activity using the $\mathrm{DPPH}$ method. A high $\mathrm{IC}_{50}$ value was found, which may be linked to the presence of gallic acid and ethyl gallate (Ascari et al., 2010). Aqueous and ethanolic extracts of pulp, seeds and barks from C. brasiliense (pequi) and other fruits, known to be consumed mainly by the native population of Cerrado region in Brazil, were evaluated for their free radicals scavenging activity, by using DPPH assay. Aqueous

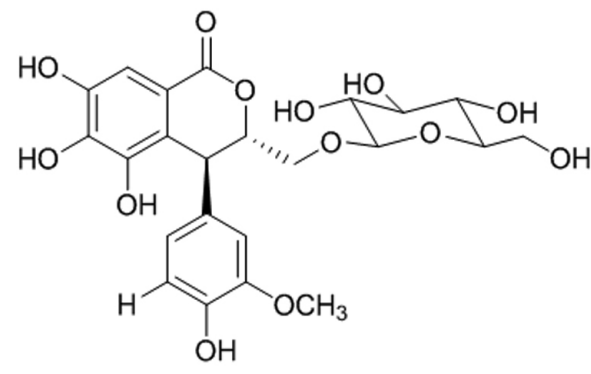

152<smiles>COc1cc([C@H]2c3c(cc(O)c(O)c3O)C(=O)O[C@@H]2COC2OC(CO)C(O)C3OCC23O)cc(OC)c1O</smiles>

153

FIGURE 10. The new dihydroisocoumarin glucosides from the stem barks of C. glabrum. 
and ethanolic extracts of pequi peels presented $\mathrm{IC}_{50}=9.4$ and $17.9 \mu \mathrm{g} / \mathrm{mL}$, respectively. Gallic acid (52), used as a reference compound, presented $\mathrm{IC}_{50}=1.4 \mu \mathrm{g} / \mathrm{mL}$. Determination of total phenols for these extracts has been accomplished by the FolinCiocalteau assay. Ethanolic and aqueous extracts of the pequi fruit peels presented values of 209.37 and $208.42 \mathrm{~g} \mathrm{GAE} / \mathrm{kg}$, respectively in this assay. Both extracts showed to be rich in phenolic compounds by using the same method having, in consequence, high scaveneging activity (Roesler et al., 2007). Antioxidant activity of pequi fruit ethanolic extract was also assessed using lipid peroxidation in vitro model, using rats liver microsomes as an oxidative system. The extract showed high antioxidant activity; the respective $\mathrm{IC}_{50}$ has not exceeded $0.8 \mu \mathrm{g} / \mathrm{mL}$ (Roesler et al., 2008).

Alelophatic activity in the growth of $L$. sativa (lettuce) was evaluated for crude ethanolic extract and compounds isolated from the epicarp and mesocarp of $C$. brasiliense. Among the samples tested, gallic acid presented greater inhibitory effect on root and high stimulatory effect on the stem. The same extract and fractions were also evaluated for antimicrobial activity on microorganisms $S$. aureus, Salmonella typhymurium, E. coli, Citrobacter freundi, Bacillus cereus, L. monocytogenes, $P$. aeruginosa and C. albicans, demonstrating activity for all bacteria tested but not against the yeast $C$. albicans (Ascari et al., 2010).

Crude ethanolic extract, ethyl acetate fraction and epicuticular wax of leafes (collected in March and October), in addition to the oils from seed and almonds of $C$. brasiliense were tested for the inhibition of 23 isolates of Cryptococcus neoformans, being 19 isolates of $C$. neoformans var. neoformans and 4 of $C$. neoformans var. gattii. Crude ethanolic extract presented antifungal activity (89\% inhibition) against C. neoformans var. neoformans. The epicuticular wax collected in October presented greater antifungal activity than the wax collected in March and presented growth inhibition of $73 \%$ of $C$. neoformans var. neoformans. Fixed oils from both, seeds and almonds, as well as the ethyl acetate fraction, presented high fungistatic activity on C. neoformans. In respect of the two varieties of Cryptococcus tested, the analysis of the in vitro susceptibility showed that $C$. neoformans var gatii possessed lower sensitivity to extracts of C. brasiliense than $C$. neoformans var. neoformans (Passos et al., 2002).

In another study, the aqueous extract of $C$. brasiliense pulp showed anticlastogenic activity and was able to inhibit damage on bleomycin-induced DNA in mice. The extract also presented antiproliferative activity when tested in vitro in Chinese hamster cells. Through this study it was seen that the clastogens bleomycin and cyclophosphamide were effective as positive controls in DNA damage to be used in the $\mathrm{CHO}-\mathrm{K} 1$ bioassay (Chinese hamster ovary cells). The antioxidant property of aqueous extract was assessed using the degradation of 2-deoxyribose in the Fenton reaction. It was noticed that the extract inhibited the Fenton reaction, decreasing the formation of hydroxyl radical and reducing oxidative degradation of 2-deoxyribose (Khouri et al., 2007).

The toxicity of $C$. brasiliense was evaluated to analyze changes in mitotic index of Guaru gills (Poecilia vivipara) epithelial cells exposed to fractions obtained from leaves and stem barks of pequi extracted with ethyl acetate. There were not detected significant changes in mitotic index, in comparison with control group (Motter et al., 2004).

$C$. brasiliense extracts were assayed for molluscicidal activity against $B$. glabrata, toxicity to Artemia salina, antifungal activity against Cladosporium sphaerosperum by autobiography and antibacterial activity by agar diffusion test against $S$. aureus, E. coli, B. cereus and $P$. aeruginosa. The leaves extract showed high cytotoxic activity against larvae of $A$. salina and also antibacterial activity against microorganisms $S$. aureus, $B$. cereus and $P$. aeruginosa (Alves et al., 2000).

The potential of $C$. brasiliense fruit oil as promoter of in vitro sodium diclofenac penetration through human skin was tested. It was noticed that the combination of pequi oil and papain showed a better performance in formulations than pequi oil alone (Lopes et al., 2008). Intersterification of pequi oil with stearic acid catalyzed by specific sn 1.3-1.3 lipase Lipozyme, showed efficient incorporation of stearic acid into pequi oil triglycerides (Facioli et al., 1998).

The ability of chloroform and aqueous extracts of $C$. brasiliense pulp to protect cells against genotoxicity induced by two antineoplasic drugs, cyclophosphamide injection (CP) and bleomycin (BLM) was evaluated. The pulp fruit extracts did not present clastogenic or genotoxic effect in the studied cells. Both extracts showed protective effects against oxidation damage in DNA caused by $\mathrm{CP}$ and $\mathrm{BLM}$, indicating ability to inhibit in vivo chemical mutagenesis. There was a differentiation on the results in relation to the gender of the mice tested. The antioxidant activity of extracts was also evaluated by measurement of lipid peroxidation by TBARS in mice plasmas. Chloroform extracts enhanced lipid peroxidation only in male animals with no significant effect on females. These results suggest that, with appropriate adjustment in the dosis, the organic extract can be used as a supplement in the diet (Miranda-Vilela et al., 2008).

The same group has evaluated the protective antioxidant effects of pequi oil in runners. This study 
was carried with athletes divided in two groups. Both groups run the same distance in a race, at the same time and under the same environmental conditions (before and after taking pequi oil as a supplement). It was noted that the pequi oil was effective in reducing tissue injuries, based on the values of proteins aspartate aminotransferase (AST) and alanine aminotransferase (ALT), especially in women. Pequi oil also caused reduction of DNA damage in athletes, regardless the gender. Protein creatine kinase (CK) levels were influenced by the MnSOD genotypes; heterozygotes individuals had less damage in DNA and smaller tissue injuries and a decrease in the levels of lipid peroxidation. These proteins presented better response to the pequi oil against damage induced by exercise. Therefore, pequi oil showed to be a good antioxidant supplement besides possessing many other nutritional properties (Miranda-Vilela et al., 2009b).

The anti-inflammatory power of $C$. brasiliense (pequi) oil and its effects on management of postprandial lipidemia and on the blood pressure of female and male athletes was also evaluated by Miranda-Vilela group. Athletes participating of this study were evaluated after racing (under the same conditions) before and after ingestion of capsules containing $400 \mathrm{mg}$ of pequi oil for 14 days. Pequi oil presented anti-inflammatory effect and reduced total cholesterol, HLD and low-density lipoprotein in participants aged above 45 years, mostly the male ones. There was a decrease in blood pressure, suggesting that pequi oil, when used as a supplement for athletes, have a hypotensive effect (Miranda-Vilela et al., 2009c). The study followed to evaluate the effects of pequi oil on oxidative exercise-induced damage in plasma and erythrocytes. The athletes were subjected to weekly training under the same conditions. The assessment was made before and after the ingestion of capsules containing $400 \mathrm{mg}$ of pequi oil for 14 days. Blood samples were analyzed after they raced and were subjected to TBARS test and to an erithrogram analysis. To verify if the antioxidant effect of pequi oil was influenced by antioxidant enzyme genotypes, polymorphisms MnSOD (Val9Ala), CAT (21A/T) and GPX1 (Pro198Leu) genes were analyzed. It was observed that the pequi oil assists in the improvement of exercising in athletes because of its ability to carry oxygen through the blood. The best result in treatment using the pequi oil was presented by individuals that have proalell genotypes MnSOD Val / Val, CAT AA or AT and GPX1 (Miranda-Vilela et al., 2010).

Dermocosmetic activity of the saponins 82 and 134, isolated from methanolic extract of $C$. villosum stem barks, was evaluated. Ex vivo lipolitic activity was not observed using a human adipose tissue explant in the concentration of $100 \mu \mathrm{g} / \mathrm{mL}$ and no inhibition of DOPA oxidase activity was observed at a concentration of $50 \mu \mathrm{g} / \mathrm{mL}$. A moderate in vitro cytotoxic activity was noticed against keratinocyte cells for 134 and for 82 (Magid et al., 2006a).

Methanolic extracts of both, pulp and peels of $C$. villosum fruit, as well as the fraction rich in saponins from the peels were evaluated for toxicity by brine shrimp ( $A$. salina) assay. All samples tested showed good larvicidal activity. Methanolic extract from the pulp presented $\mathrm{LC}_{50} 100 \mu \mathrm{g} / \mathrm{mL}$ being more toxic to the methanolic extract of the peels $(500 \mu \mathrm{g} / \mathrm{mL})$. The fraction rich in saponins from the fruit peels showed a $\mathrm{LC}_{50}$ value of $100 \mu \mathrm{g} / \mathrm{mL}$, and a mortality rate of $17 \%$ at $10 \mu \mathrm{g} / \mathrm{mL}$, being more active than the methanolic extracts. The antimicrobial activity of saponins $121,123,124,137$ and $3-O-\beta-$ D-glucopyranosyl-( $1 \rightarrow 2)-\beta$-D-galactopyranosyl hederagenin-28-O- $\beta$-D-glucopyranosyl ester (154) was evaluated against E. coli, S. aureus, $P$. aeruginosa, Mycobacterium smegmatis and Enterococcus faecalis. However, at the used doses, none of these compounds were active against these micro-organisms (Magid et al., 2006b).

The hemolytic activity of metahanol extracts from peels and skin of $C$. glabrum fruit, as well as of ten saponins isolated from the fruit pulp (123, $124,126,133,134,135,136,138,145$ and 154) were evaluated, showing to be less active that the reference saponin mixture used in the bioassay. The monodesmosidic saponin, 124 and 134 showed greater hemolytic activity than bidesmosidic saponins 126 and 138. The disaccharide saponin 134 was more active than the monosaccharide saponin 154. These results demonstrate that bidesmosidic saponins are generally less haemolytic than the monodesmosidic ones and that hemolytic activity increases with the number of sugar units attached in position 3 of the aglicon (Magid et al., 2006c).

Leaves of C. microcarpum presented repellent activity/toxicity against cutting leaves ants. These leaves are used by the indians of Northwestern Amazonia as well as the pulp of C. glabrum, C. gracile and $C$. microcarpum fruits as fish poison. This application is related to the presence of saponins in this part of the plant (Kawanishi et al., 1986).

\section{CONCLUSION}

Caryocaraceae family, distributed in Central and South America, presents two genera, Anthodiscus and Caryocar. Plants from Anthodiscus genus have not been targeted by phytochemical studies so far, and its use has been restricted as a wooden source. By the other hand, there are several reports on the phytochemical constituents and biological studies of species from Caryocar genus. 
The fruits of many Caryocar species are used to produce oil and in the culinary, in the elaboration of several foods due to their high contents of vitamins, lipids and proteins. The oil, also very used in the cosmetic and food industries, possesses high amounts of unsaturated fatty acids like palmitic and oleic acids. Amongst the species of Caryocar genus, oils from the fruit pulp of $C$. brasiliense, $C$. villosum and C. glabrum were chemically and biologically studied, as well as the almond of $C$. brasiliense. Levels of carotenoids in the $C$. brasiliense and C. villosum fruit pulp were determined. In $C$. brasiliense, the major found was anteraxantin and, in $C$. villosum, $b$-cryptoxanthin and $b$-carotene were the predominat ones. The composition of volatile compounds present in fruits pulp and in the seeds of $C$. brasiliense and $C$. villosum was studied and $C$. brasiliense presented ethyl hexanoate as the major constituent in the pulp and in the seed. C. brasiliense presents several phenol compounds confirming the antioxidant activity reported for its fruit. C. glabrum and $C$. villosum are rich in saponins. Caryocar species demonstrated great biological potential. C. brasiliense was active against $B$. glabrata, $T$. cruzi, $L$. amazonensis and inhibited the growth of the bacteria $S$. aureus and $P$. aeruginosa. Several pre-clinical and toxicological studies confirm the antioxidant activity of C. brasiliense. C. brasiliense did not present clastogenic or genotoxic effects in mice cells but instead, protected them against DNA damages induced by bleomycin or ciclosphosfamide. The oil of $C$. brasiliense also has cardiovascular protective effect, and can be used as a dietary supplement. In this way, this review brings about the great potential of plants from Caryocar genus.

\section{ACKNOWLEDGEMENTS}

This work has been supported by FAPEMIG, a Minas Gerais State (Brazil) Foundation, by CNPq and by CAPES, Brazilian Government Agencies that act in human resources formation and in the financial support of scientific research.

\section{REFERENCE}

ALMEIDA, S.P.; PROENÇA, C.E.B.; SANO, S.M.; RIBEIRO, J.F. Cerrado: espécies vegetais úteis. EMBRAPA-CPAC. 1998. 464p.

ALVES, T.M.A. et al. Biological screening of Brazilian Medicinal Plants. Memórias do Instituto Oswaldo Cruz, v.95, n.3, p.367-373, 2000.

ARAÚJO, F.D. A review of Caryocar brasiliense (Caryocaracea) - an economically valuable species of the central Brasilian cerrados. Economy Botany, v.49, p.40-48, 1995.

ASCARI, J. et al. Phytochemical and biological investigations of Caryocar brasiliense Camb. Boletín Latinoamericano y del Caribe de Plantas Medicinales y Aromáticas, v.9, p.20-28, 2010.

AZEVEDO-MELEIRO, C.H.; RODRIGUEZ-AMAYA, D.B. Conûrmation of the identity of the carotenoids of tropical fruits by HPLC-DAD and HPLC-MS. Journal of Food Composition and Analysis, v.17, p.385-396, 2004.

BARRADAS, M. M. Informações sobre floração e frutificação e dispersão do piqui Caryocar brasiliense Camb. (Caryocaracea). Ciência e Cultura, v.24, p.1063- 1075, 1972.

BENDER, D.A. As vitaminas. In: GIBNEY, M. J. et al. Introdução à nutrição humana. Rio de Janeiro: Guanabara Koogan, 2005, p.114-161.

BERRY, E.M. et al. Effects of diets rich in monounsaturated fatty acids on plasma lipoproteins the Jerusalem Nutrition Study: high MUFAs vs high PUFAs. American Journal Clinical Nutrition, v.53, p.899-907, 1991.

BEZERRA, J.C.B. et al. Molluscidal activity against Biomphalaria glabrata of Brazilian cerrado medicinal plantas. Fitoterapia, v.73, p.428-430, 2002.

DICKISON, W.C. A study of the floral morphology and anatomy of the Caryocaracea. Bulletin of the Torrey Botanical Club, v.117, n.2, p.123-137, p.1990.

FACIOLI, N.L.; GONÇALVEZ, L.A.G. Modificação por via enzimática da composição triglicerídica do óleo do pequi (Caryocar brasiliense Camb.). Química Nova, v.21, p.16-19, 1998.

GODOY, H.T. Estudo de carotenóides e pró-vitamina A em alimentos. 1993. Tese de doutorado. Universidade Estadual de Campinas. Faculdade de Engenharia de Alimentos. Campinas, São Paulo.

GODOY, H.T.; RODRIGUEZ-AMAYA, D.B. Occurrence of cis-isomers of provitamina A in Brazilian fruits. Journal of Agriculture Food Chemistry, v.42, p.1306-1313, 1994.

HANNA, S.J. et al. A study of oleic acid and 2,4-DHB acid aerosol using an IR-UV-IT-MS : insights into the strengths and weaknesses of the technique. Physical Chemistry Chemical Physics, v.11, p.7963-7975, 2009.

HERZOG-SOARES, J.D. et al. Atividade tripanocida in vivo de Stryphnodendron adstringens (barbatimão verdadeiro) e Caryocar brasiliensis (pequi). Revista Brasileira de Farmacognosia, v.12, p.11-15, 2002.

HERZOG-SOARES, J.D. et al. Bioatividade de Stryphnodendron adstringens, S. polyphyllum, C. brasiliense, plantas do cerrado brasileiro, sobre Trypanosoma cruzi "in vivo". Bioscience Journal, v.22, n.3, p.113-118, 2006.

KAWANISHI, K., RAFFAUF, R. F. Caryocar microcarpum: an ant repelent and fish poison of the northwest Amazon. Journal of Natural Products, v.49, p.1167-1168, 1986.

KHOURI, J. et al. Anticlastogenic potential and antioxidant effects of na aqueous extract of pulp from the pequi tree (Caryocar brasiliense Camb.). Genetics and Molecular Biology, v.30, n.2, p.442-448, 2007.

LIMA, M.T. et al. Composição de ácidos graxos da fração lipídica do pequi (Caryocar coriaceum Wittm.). Ciência Agronômica, v.12, p.93-96, 1981.

LIMA, A. et al. Composição química e compostos bioativos presentes na polpa e na amêndoa do pequi (Caryocar brasiliense Camb.). Revista Brasileira de Fruticultura, v.29, p.695-698, 2007.

Rev. Bras. Pl. Med., Campinas, v.15, n.2, p.293-308, 2013. 
LOPES, P.S. et al. Evaluation of in vitro percutaneous enhancement effect of papain and pequi oil on diclofenac sodium permeation through human skin. Brazilian Journal of Pharmaceutical Sciences, v.44, n.2, p.225-231, 2008.

LORGERIL, M.; SALEN P. The Mediterranean diet in secondary prevention of coronary heart disease. Clinical \& Investigative Medicine, v.29, p.154-158, 2006.

MACEDO, A.L. et al. Pequi cake composition, hydrolysis and fermentation to bioethanol. Brazilian Journal of Chemical Engineering, v.28, n.1, p.9-15, 2011.

MAIA, J.G.S. et al. Aroma volatiles of pequi fruit (Caryocar brasiliense Camb.). Journal of Food Composition and Analysis, v.21, p.574-576, 2008.

MAGID, A.A. et al. Triterpenoid saponins from the stem bark of Caryocar villosum. Phytochemistry. v.67, p.2096-2102, 2006a.

MAGID, A.A. et al. Triterpenoid saponins from the fruits of Caryocar villosum. Journal of Natural Products, v.69, p.919-926, 2006b.

MAGID, A.A. et al. Triterpenoid saponins from the fruits of Caryocar villosum. Journal of Natural Products, v.69, p.196-205, 2006c.

MAGID, A.A. et al. Dihydroisocoumarin glucosides from stem bark of Caryocar glabrum. Phytochemistry, v. 68, p.2439-2443, 2007.

MAGID, A.A. et al. Phenolic Glycosides from the Stem Bark of Caryocar villosum and Caryocar glabrum. Journal of Natural Products, v. 71, p.914-917, 2008.

MARQUES, M.C.S. et al. Efeito fungitóxicos dos extratos de Caryocar brasiliense Camb. sobre os fungos Botritys cinera, Colletotrichum truncatum e Fusarium oxysporum. Ciência Agrotécnica, Ed. Especial. p.1410-1419, 2002.

MARX, F. et al. Chemical composition of the fruit pulp of Caryocar villosum. Zeitschrift für Lebensmittel Untersuchung und Forschung A, v.20, p.442-444. 1997.

MIRANDA-VILELA, A.L. et al. Antigenotoxic activity and antioxidant properties of organic and aqueous extracts of pequi fruit pulp (Caryocar brasiliense Camb.). Genetics an Molecular Biology, v.31, n.4, p.956-963, 2008.

MIRANDA-VILELA, A.L. et al. Characterization of the major nutritional components of Caryocar brasiliense fruit pulp by NMR spectroscopy. Química Nova, v.32, n.9, p.2310-2313, 2009a.

MIRANDA-VILELA, A.L. et al. Dietary carotenoid-rich pequi oil reduces plasma lipid peroxidation and DNA damage in runners and evidence for an association with MnSOD genetic variant -Val9Ala. Genetis and Molecular Research, v.8, p.1481-1495. 2009b.

MIRANDA-VILELA, A.L. et al. Pequi fruit (Caryocar brasiliense Camb.) pulp oil reduces exercise-induced inflammatory markers and blood pressure of male and female runners. Nutrition Research, v.29, p.850-858, 2009c.

MIRANDA-VILELA, A.L. et al., Dietary carotenoidrich oil supplementation improves exercise-induced anisocytosis in runners: influences of haptoglobin, MnSOD (Val9Ala), CAT (21A/T) and GPX1 (Pro198Leu) gene polymorphisms in dilutional pseudoanemia ("sports anemia"). Genetics and Molecular Biology, v. 33, p.359-367, 2010.

MOTTER, M.D.S. et al. Índice mitótico em células epiteliais da brânquia de Guaru (Poecilia vivípara) tratados com frações da casca do caule e da folha de pequi (Caryocar brasiliensis). Brazilian Journal of Veterinary Research and Animal Science, v. 41, p.221-227, 2004.

NAVARRO-TITO, N. et al. Oleic acid promotes migration on MDA-MB-231 breast cancer cells through an arachidonic acid-dependent pathway. The International Journal of Biochemistry \& Cell Biology, v. 42, p.306-310, 2010.

OLIVEIRA, M.M. et al. Triterpenes in Caryocar brasiliense, Anais da Academia Brasileira de Ciências, v. 40, p.451-452, 1968.

PAULA-JUNIOR, W. et al. Leismanicidal, antibacterial, and antioxidant activities of Caryocar brasiliense Camb. Leaves hydroethanolic extract. Revista Brasileira de Farmacognosia, v.16, p.625-630, 2006.

PASSOS, X.S. et al. Antifungal activity of Caryocar brasiliense (Caryocaraceae) against Cryptococcus neoformans. Revista da Sociedade Brasileira de Medicina Tropical, v.35, p.623-627, 2002.

PASSOS, X.S. et al. Composition and antifungal activity of essential oils of Caryocar brasiliensis. Pharmaceutical Biology, v.41, p.319-324, 2003.

PONTES-ARRUDA, A. Biological benefits of an oleic acid-rich lipid emulsion for parenteral nutrition. Clinical Nutrition Supplements, v.4, p.19-23, 2009.

PRANCE, G.T.; Silva, M.F. Caryocaraceae. Flora Neotropica. Hafner, New York. v.12, p.1-75, 1973.

PRANCE, G.T. The genus Caryocar L. (Caryocaraceae): an underexploited tropical resource. Advances in Economic Botany, v. 8, p.177-188, 1990.

RAMOS, M.I.L. et al. Efeito do cozimento convencional sobre os carotenóides pró-vitaminicos "A" da polpa do piqui (Caryocar brasiliense Camb.). Boletim do Centro de Pesquisa de Processamento de Alimentos, v.19, n.1, p.23-32, 2001.

ROESLER, R. et al. Atividade antioxidante de frutas do cerrado. Ciência e Tecnologia de Alimento, v.27, p.53-60, 2007.

ROESLER, R. et al. Antioxidant activity of Caryocar brasiliense (pequi) and characterisation of components by electrospray ionization mass spectrometry. Food Chemistry, v.110, p.711-717, 2008.

SCHENKEL, E.P. et al. Saponinas. In: SIMÕES, C.M.O. Farmacognosia: da planta ao medicamento. 5.ed. Porto Alegre: UFRGS, 2003. 1102p.

SEGALL, S.D. et al. Triacylglycerol analysis of pequi (Caryocar brasiliense Camb.) oil by electrospray and tandem mas spectrometry. Journal of the Science of Food and Agriculture. v. 86, p.445-452, 2006.

STEIN, O. et al. Effects of oleic acid and macrophage recruitment on cholesterol efflux in cell culture and in vivo. Metabolism \& Cardiovascular Diseases, v.18, p.596-601, 2008.

TERÉS, S. et al. Acid oleic content is responsable for the reduction in blood pressure induced by olive oil. Proceedings of the National Academy of Sciences of the United States of America, v.105, n.37, p.1381113816, 2008. 